Article

\title{
On the Physicochemical Characteristics and Applications of an "Undesirable" Pyrenean Thorny Cushion Dwarf: Echinospartum horridum (Vahl) Roth
}

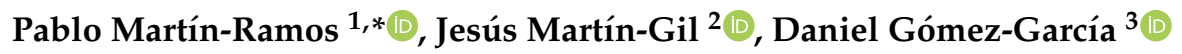 \\ and José Antonio Cuchí-Oterino ${ }^{4}$ (i) \\ 1 Instituto Universitario de Investigación en Ciencias Ambientales de Aragón (IUCA), EPS, \\ Universidad de Zaragoza, Carretera de Cuarte, s/n, 22071 Huesca, Spain \\ 2 Agriculture and Forestry Engineering Department, ETSIIAA, Universidad de Valladolid, \\ Avenida de Madrid 44, 34004 Palencia, Spain; mgil@iaf.uva.es \\ 3 Instituto Pirenaico de Ecología (CSIC). Avda. Ntra. Sra. de la Victoria 16, 22700 Jaca, Spain; \\ dgomez@ipe.csic.es \\ 4 Instituto Universitario de Investigación en Ingeniería de Aragón (I3A), EPS, Universidad de Zaragoza, \\ Carretera de Cuarte, s/n, 22071 Huesca, Spain; cuchi@unizar.es \\ * Correspondence: pmr@unizar.es; Tel.: +34-974-292668
}

Received: 27 July 2020; Accepted: 9 September 2020; Published: 11 September 2020

\begin{abstract}
Small evergreen shrubs of the family Fabaceae represent a large proportion of current Mediterranean mountain vegetation. Their low pastoral value and tendency for encroachment makes these plants undesirable. In this paper, the thermal and chemical characteristics of Echinospartum horridum, a thorny cushion-shaped dwarf shrub native to the French Central Massif and the Pyrenees (particularly dominant in the shrublands of the Pyrenees), have been analyzed with a view to its valorization. Although the higher and lower heating values of the biomass from E. horridum met the ISO 17225-2:2014 requirements for its use in pellets, the ash content was slightly above the upper limit, so it would not comply with the normative for its acceptable use as a fuel. Nevertheless, the presence of high added-value flavonoids and lignans in its extracts, which are receiving increasing recent interest as efficient anti-tumor drugs and antivirals, may open the door to the valorization of this shrub for pharmacological applications.
\end{abstract}

Keywords: erizón; ESI-TOF; genkwanin; shrublands; thermal analysis; Pyrenees

\section{Introduction}

Echinospartum horridum, commonly called "erizón", "abrizón”, "escarpín” or "tollaga" is a long-lived (up to 30-40 years) perennial shrub of the Fabaceae family, endemic of the south-west extreme of Europe. Its distribution area is restricted to the central-western sector of the Pre-Pyrenees and Pyrenees ranges (from Leoz and Roncal Valleys in Navarra to the Ribagorza in Aragon) and barely crosses the borderline to the French northern slope (Figure 1). It may also be found in a tiny village in the Massif Central in France. 


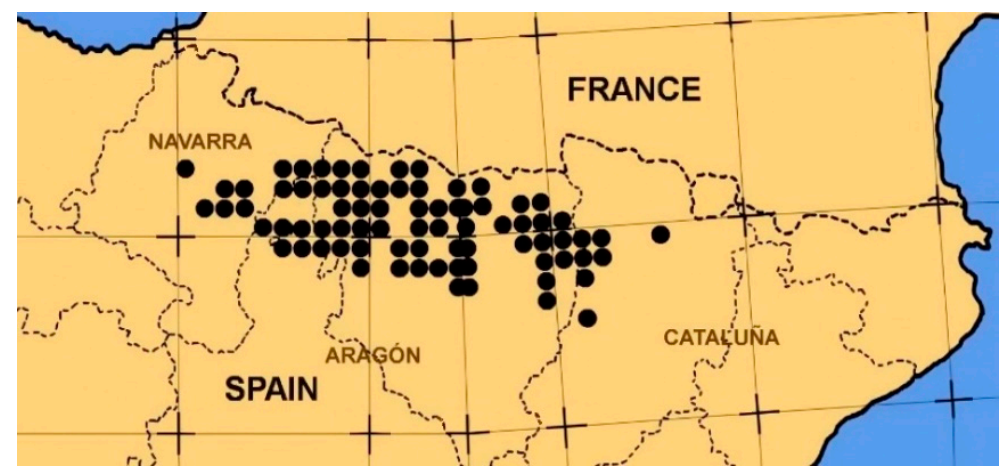

Figure 1. Echinospartum horridum distribution in the Pyrenees mountain range.

As for its morphology, E. horridum is a taprooted, thorny, cushion-shaped shrub with a very dense structure, which can exceed $50 \mathrm{~cm}$ in height and $1 \mathrm{~m}$ in diameter. Branch and stipule apexes are bristly. The leaf is composed, with three lanceolate, hairy below, early-falling leaflets of only $5-8 \times 1 \mathrm{~mm}$. The bright yellow flowers are $1 \mathrm{~cm}$ long, solitary or, most often, grouped in pairs. The fruit is a legume covered with silky hairs, 1-2 cm long with 1-3 ovoid and blackish seeds (Figure 2). The flowering period is between June and July, according to altitude.
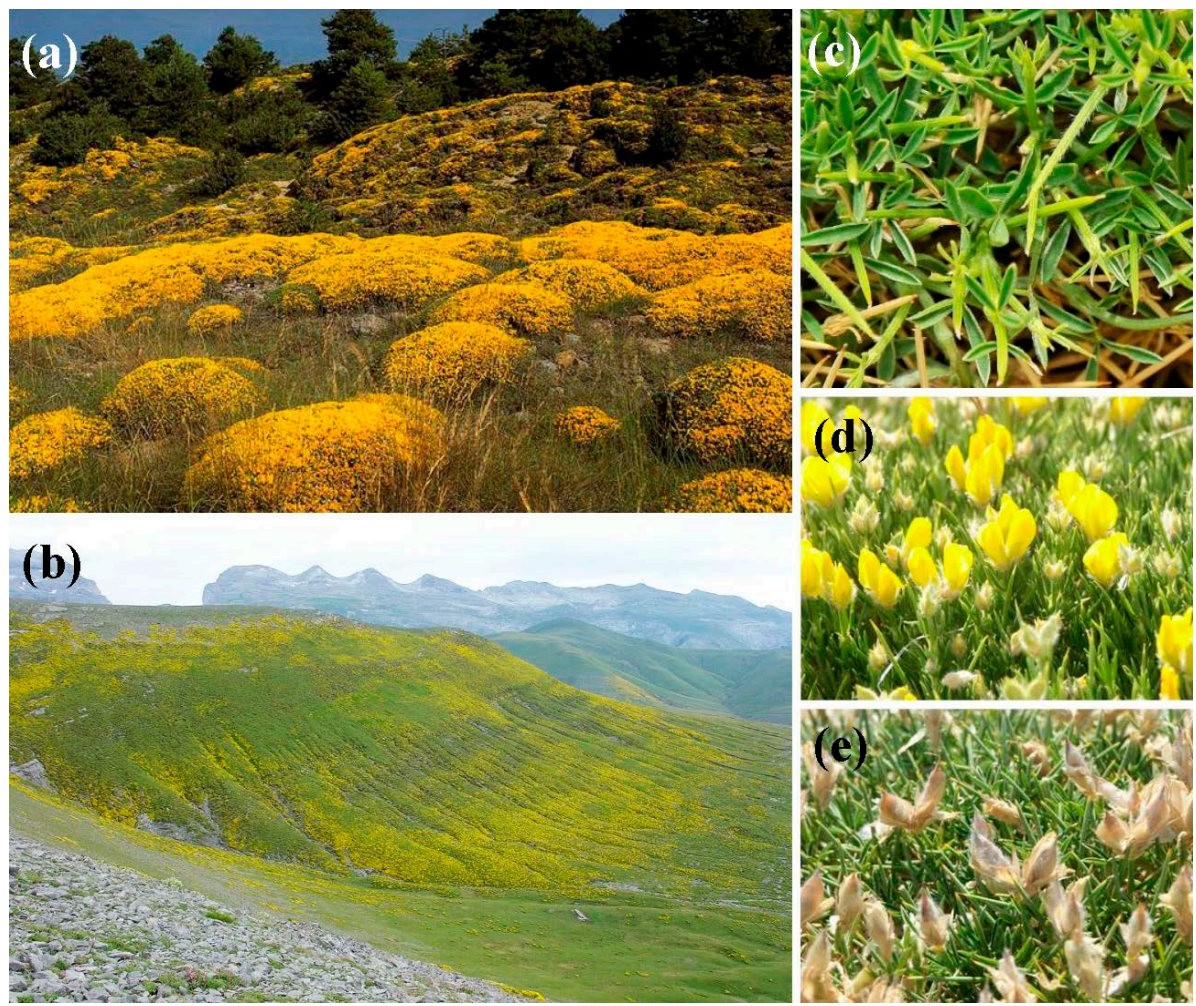

Figure 2. (a,b) E. horridum shrublands in Sierra de las Cutas, Ordesa-Monte Perdido National Park, Huesca, Spain; (c) leaves; (d) flowers; and (e) fruits.

E. horridum is found at between 400 and $2344 \mathrm{~m}$, although its greatest abundance is observed between 1000 and $1700 \mathrm{~m}$ [1]. It grows on calcareous or marlstone substrates. Its primary habitat is ridges and rocky slopes, where it forms dense shrublands that constitute permanent communities, i.e., unable to evolve into forest in the short term (Figure 2). Thanks to its deep roots, morphology and phenology, this shrub withstands the summer drought of the environments it occupies, focusing its organogenesis in spring (April and May) [2,3]. The plant is unable to re-sprout, but its seeds germinate vigorously, especially after fire or thinning of vegetation. 
In the last few years, an increase of Pyrenean grassland encroachment, mainly due to this shrub, has been reported [4], and prescribed burning and mechanical clearing, in order to control the expansion of the bush, are being carried out. These actions, apart from being costly and sometimes harmful due to the use of machinery in abrupt topographies, are proving ineffective due to the aforementioned germination capacity of this shrub [5]. Studies on burning treatment and the fire's thermal signature in areas covered by this shrub have been reported by Badía et al. [5,6].

The nutritive value of E. horridum is constrained by its high lignin content, which restricts the availability of nutritive palatable pasture barely past the seedling stage $[7,8]$ : only the tender buds and flowers are consumed by sheep and goats. The low pastoral value, together with the abundant spinescence, highlight the difficulty in controlling the expansion of this species via grazing and challenge the suitability of prescribed burning for fighting shrub encroachment [9].

However, although this bush is widely regarded as undesirable, it should be noted that it is able to maintain the soil in environments very prone to erosion and that it fixes atmospheric nitrogen, thus contributing to the improvement of the soils where it is located. Moreover, the leaflets and stems of Genistae (Echinospartum spp.) have been reported to be rich in daidzein, formononetin, genistein, 5-O-methylgenistein, biochanin A and 5-O-methylbiochanin A isoflavones [10,11].

Since, at present, this shrub is considered a problem and the control of its expansion is ineffective, it seems appropriate to test the possibility of its economic exploitation. The aim of this study has been to investigate its thermal and chemical characteristics with a view to its valorization, in line with other European Union-sponsored studies directed towards the valorization of the underused natural resources of shrublands.

\section{Results and Discussion}

\subsection{Fuel Characterization and Biomass Combustion Properties}

\subsubsection{Elemental Analysis}

The $\mathrm{C}, \mathrm{H}$, and $\mathrm{N}$ percentages of $\mathrm{E}$. horridum components ( $\mathrm{wt} \%$ of dry material) were in the $48.3-50.3 \%, 6.51-6.56 \%$ and $0.90-2.08 \%$ range, respectively (Table 1 ). These values are in good correspondence with the overall chemical composition reported for other shrubs, such as C. ladanifer $(47.8 \% \mathrm{C}, 6.4 \% \mathrm{H}$ and $0.8 \% \mathrm{~N})$ or E. arborea $(51.0 \% \mathrm{C}, 6.2 \% \mathrm{H}$ and $1.0 \% \mathrm{~N})$ [12].

Table 1. Elemental (CHNS) composition (wt\%) of E. horridum fractions.

\begin{tabular}{cccccc}
\hline Sample & $\mathbf{\% C}$ & $\mathbf{\% H}$ & $\mathbf{\% N}$ & $\mathbf{\% S}$ & C/N Ratio \\
\hline Leaflets/green stems & 48.27 & 6.53 & 2.08 & 0.00 & 23.2 \\
Brown stems & 49.88 & 6.51 & 0.90 & 0.00 & 55.4 \\
Little branches (twigs) & 50.27 & 6.56 & 1.05 & 0.00 & 47.9 \\
\hline Sulfamethazine standard & 51.86 & 5.05 & 20.13 & 11.41 & \\
Sulfamethazine sample & 51.75 & 5.09 & 20.49 & 11.83 & \\
\hline
\end{tabular}

The distribution of nitrogen content, with maximum values in the leaves and decreasing by half in the stems and branches, is in agreement with that reported by García Rosa [13] for C. ladanifer fractions. Regarding the $\mathrm{C} / \mathrm{N}$ ratio values, those obtained for the leaves (23.2\%) are similar to those found for C. ladanifer (26.5\%), but half of those obtained for E. arborea (50.5\%) [12].

\subsubsection{Higher Heating Values Derived from Elemental Analysis Data}

The calculated higher heating values (HHV) for green stems, brown stems and twigs were 19.67, 20.4 and $20.63 \mathrm{~kJ} \cdot \mathrm{g}^{-1}$, respectively, with a mean value of $20.2 \mathrm{~kJ} \cdot \mathrm{g}^{-1}$. For comparison purposes, the HHV values for other Mediterranean shrubs, i.e., C. ladanifer and E. arborea, ranged from 19.2 to $20.5 \mathrm{~kJ} \cdot \mathrm{g}^{-1}$ and from 19.7 to $21.3 \mathrm{~kJ} \cdot \mathrm{g}^{-1}$, respectively [14]. Regarding the applicability of the above shrubs as 
fuels, the European standard for wood pellets (EN 14961-2) establishes that the HHV should be $\geq 18.82 \mathrm{~kJ} \cdot \mathrm{g}^{-1}$ [15], so E. horridum aerial samples would be compliant.

\subsubsection{Component Percentages}

Mass fractions of the different constituents and fresh and dry weights for four E. horridum samples are reported in Table 2. Weighted average moisture content values ranged from $13.2 \%$ to $18.5 \%$, lower than that reported for C. ladanifer (26.8\%) and E. arborea (26\%).

Table 2. Moisture values for E. horridum.

\begin{tabular}{|c|c|c|c|c|c|c|c|}
\hline Sample & Fraction & $\begin{array}{l}\text { Mass Fraction } \\
(w t \%)\end{array}$ & $\begin{array}{c}\text { Fresh } \\
\text { Weight (g) }\end{array}$ & $\begin{array}{c}\text { Dry } \\
\text { Weight (g) }\end{array}$ & $\begin{array}{l}\text { Moisture } \\
\text { (g) }\end{array}$ & $\begin{array}{c}\text { Moisture } \\
\text { Content }(w t \%)\end{array}$ & $\begin{array}{l}\text { Moisture Content (wt } \% \text {, } \\
\text { Weighted Average) }\end{array}$ \\
\hline \multirow{3}{*}{1} & $\begin{array}{l}\text { Green } \\
\text { stems }\end{array}$ & 15 & 73.94 & 55.07 & 18.87 & 34.27 & \multirow{3}{*}{18.50} \\
\hline & $\begin{array}{l}\text { Brown } \\
\text { stems }\end{array}$ & 80 & 119.1 & 103.33 & 15.78 & 15.27 & \\
\hline & Twigs & 5 & 51.66 & 42.07 & 9.59 & 22.80 & \\
\hline \multirow{3}{*}{2} & $\begin{array}{l}\text { Green } \\
\text { stems }\end{array}$ & 21 & 63.17 & 48.73 & 14.44 & 29.63 & \multirow{3}{*}{16.40} \\
\hline & $\begin{array}{l}\text { Brown } \\
\text { stems }\end{array}$ & 75 & 97.68 & 86.73 & 10.95 & 12.63 & \\
\hline & Twigs & 4 & 37.41 & 31.78 & 5.63 & 17.72 & \\
\hline \multirow{3}{*}{3} & $\begin{array}{l}\text { Green } \\
\text { stems }\end{array}$ & 28 & 30.21 & 25.12 & 5.09 & 20.26 & \multirow{3}{*}{13.50} \\
\hline & $\begin{array}{l}\text { Brown } \\
\text { stems }\end{array}$ & 70 & 69.50 & 62.75 & 6.75 & 10.76 & \\
\hline & Twigs & 2 & 15.51 & 13.51 & 2.00 & 14.80 & \\
\hline \multirow{3}{*}{4} & $\begin{array}{l}\text { Green } \\
\text { stems }\end{array}$ & 27 & 30.80 & 25.75 & 5.05 & 19.61 & \multirow{3}{*}{13.22} \\
\hline & $\begin{array}{l}\text { Brown } \\
\text { stems }\end{array}$ & 70 & 64.21 & 58.09 & 6.12 & 10.54 & \\
\hline & Twigs & 3 & 20.38 & 17.24 & 3.14 & 18.21 & \\
\hline
\end{tabular}

The results obtained for dry stems (10.5-15.3\%) were close to those reported by Badía et al. [5] (15.6-17.8\%), but noticeable differences were detected for green stems (19.6-34.3\% vs. 63.3-77.5\%) and twigs (14.8-22.8\% vs. 32.7-33.7\%). Such differences can be justified by the seasonal variability of dry matter content and its relationship with shoot growth and nonstructural carbohydrates [7].

\subsubsection{HHV Values Derived from Component Percentages}

The overall HHV for E. horridum can be estimated taking the mass fraction of each biomass component (Table 3). Given that this shrub has $15-28 \%$ of leaves/green stems, average: $21.5 \%$ $\left(\times 20.53 \mathrm{~kJ} \cdot \mathrm{g}^{-1}=4.41 \mathrm{~kJ} \cdot \mathrm{g}^{-1}\right) ; 70-80 \%$ of brown stems, average: $75 \%\left(\times 19.42 \mathrm{~kJ} \cdot \mathrm{g}^{-1}=14.56 \mathrm{~kJ} \cdot \mathrm{g}^{-1}\right)$ and $2-5 \%$ of twigs, average: $3.5 \%\left(\times 19.16 \mathrm{~kJ} \cdot \mathrm{g}^{-1}=6.7 \mathrm{~kJ} \cdot \mathrm{g}^{-1}\right)$, the weighted mean, i.e., the HHV value, was $25.6 \mathrm{~kJ} \cdot \mathrm{g}^{-1}$. 
Table 3. Weight loss (\%) and thermal effects temperatures for E. horridum constituents.

\begin{tabular}{|c|c|c|c|c|c|c|c|c|c|c|c|c|}
\hline Fraction & $\begin{array}{c}\text { Purge } \\
\text { Gas }\end{array}$ & $\begin{array}{c}\text { Weight } \\
\text { Loss (\%) }\end{array}$ & \multicolumn{5}{|c|}{ DTG $\left({ }^{\circ} \mathrm{C}\right)$} & \multicolumn{5}{|c|}{$\operatorname{DSC}\left({ }^{\circ} \mathrm{C}\right)$} \\
\hline \multirow{2}{*}{$\begin{array}{c}\text { Leaves/ } \\
\text { green } \\
\text { stems }\end{array}$} & $\mathrm{N}_{2}$ & 24.9 & 75.4 & 350.4 & 420 & 458 & & $\begin{array}{l}75.4 \\
\text { endo }\end{array}$ & $\begin{array}{l}354 \\
\text { exo }\end{array}$ & & & \\
\hline & $\mathrm{O}_{2}$ & 3.65 & 78.5 & 339.1 & & 460 & & 73.5 & $\begin{array}{l}347 \\
\text { exo }\end{array}$ & & $\begin{array}{l}483 \\
\text { exo }\end{array}$ & \\
\hline \multirow{2}{*}{$\begin{array}{l}\text { Brown } \\
\text { stems }\end{array}$} & $\mathrm{N}_{2}$ & 23.3 & 70 & 374.7 & 425.5 & 463.3 & & $\begin{array}{l}76.6 \\
\text { endo }\end{array}$ & & $\begin{array}{l}405 \\
\text { exo }\end{array}$ & & \\
\hline & $\mathrm{O}_{2}$ & 2.7 & 70 & 347.3 & 437 & 450.5 & 512 & 68 & $\begin{array}{l}365 \\
\text { exo }\end{array}$ & & $\begin{array}{l}465 \\
\text { exo }\end{array}$ & $\begin{array}{l}515.5 \\
\text { exo }\end{array}$ \\
\hline \multirow{2}{*}{$\begin{array}{l}\text { Little } \\
\text { branches } \\
\text { (twigs) }\end{array}$} & $\mathrm{N}_{2}$ & 58.9 & 66 & 374.5 & 422 & 462.7 & & $\begin{array}{l}69 \\
\text { endo }\end{array}$ & & & & \\
\hline & $\mathrm{O}_{2}$ & 4.5 & 73 & 333.0 & 441 & & 505 & & $\begin{array}{l}352 \\
\text { exo }\end{array}$ & & $\begin{array}{l}448 \\
\text { exo }\end{array}$ & $\begin{array}{l}505 \\
\text { exo }\end{array}$ \\
\hline
\end{tabular}

\subsubsection{Thermal Analysis}

The thermogravimetry (TG), derivative thermogravimetry (DTG) and differential scanning calorimetry (DSC) curves for E. horridum components are shown in Figure 3, and the temperatures of all thermal effects are summarized in Table 3. The main thermal effects, assigned to the combustion of holocellulose and lignin, are presented in Table 4.

Table 4. Main exothermic effects in the DSC curves of E. horridum fractions associated with holocellulose and lignin combustion. Those of C. ladanifer and E. arborea are included for comparison purposes [14]. $\mathrm{T}_{\text {peak }}$ stands for exotherm peak temperature.

\begin{tabular}{ccc}
\hline Species, Fraction, Purge Gas & Holocellulose (Cellulose + Hemicellulose) $\mathbf{T}_{\text {peak }}\left({ }^{\circ} \mathbf{C}\right)$ & Lignin $\mathbf{T}_{\text {peak }}\left({ }^{\circ} \mathbf{C}\right)$ \\
\hline E. horridum, green stems, $\mathrm{O}_{2}$ & 347 & 483 \\
E. horridum, brown stems, $\mathrm{O}_{2}$ & 365 & 465 \\
E. horridum, twigs, $\mathrm{O}_{2}$ & 352 & 448 \\
\hline C. ladanifer, air & 365 & 455 \\
E. arborea, air & 376 & 527 \\
\hline
\end{tabular}

\subsubsection{Ash Content}

The ash content after heating at $600{ }^{\circ} \mathrm{C}$, in $\mathrm{O}_{2}$ atmosphere, was between $2.7 \%$ and $3.6 \%$ for stems and $4.5 \%$ for branches. This would prevent their use as fuels, provided that the threshold ash content value for wood pellets—according to ISO 17225-2:2014 standard [16]—is 2\%.

\subsubsection{Lower Heating Values}

Enthalpy change values obtained from the thermal heating of brown stems and branches (Figure 3) were in the $17.8-18.3 \mathrm{~kJ} \cdot \mathrm{g}^{-1}$ range. They would correspond to lower heating values (LHV), given that they are in close correspondence with the values expected from the net calorific values of holocellulose and lignin (around 17 and $21 \mathrm{~kJ} \cdot \mathrm{g}^{-1}$, respectively [17]). The maximum LHV that could be generated by typical biomass is $20.4 \mathrm{~kJ} \cdot \mathrm{g}^{-1}$ [18] and the relatively high values for E. horridum would be in agreement with its high lignin content (215 $\mathrm{g} \cdot \mathrm{kg}^{-1}$ dry matter) [8]. Thus, LHV values for E. horridum would comply with ISO 17225-2:2014 [16]/ENplus [19] requirements $\left(\geq 16.56 \mathrm{~kJ} \cdot \mathrm{g}^{-1}\right)$. 

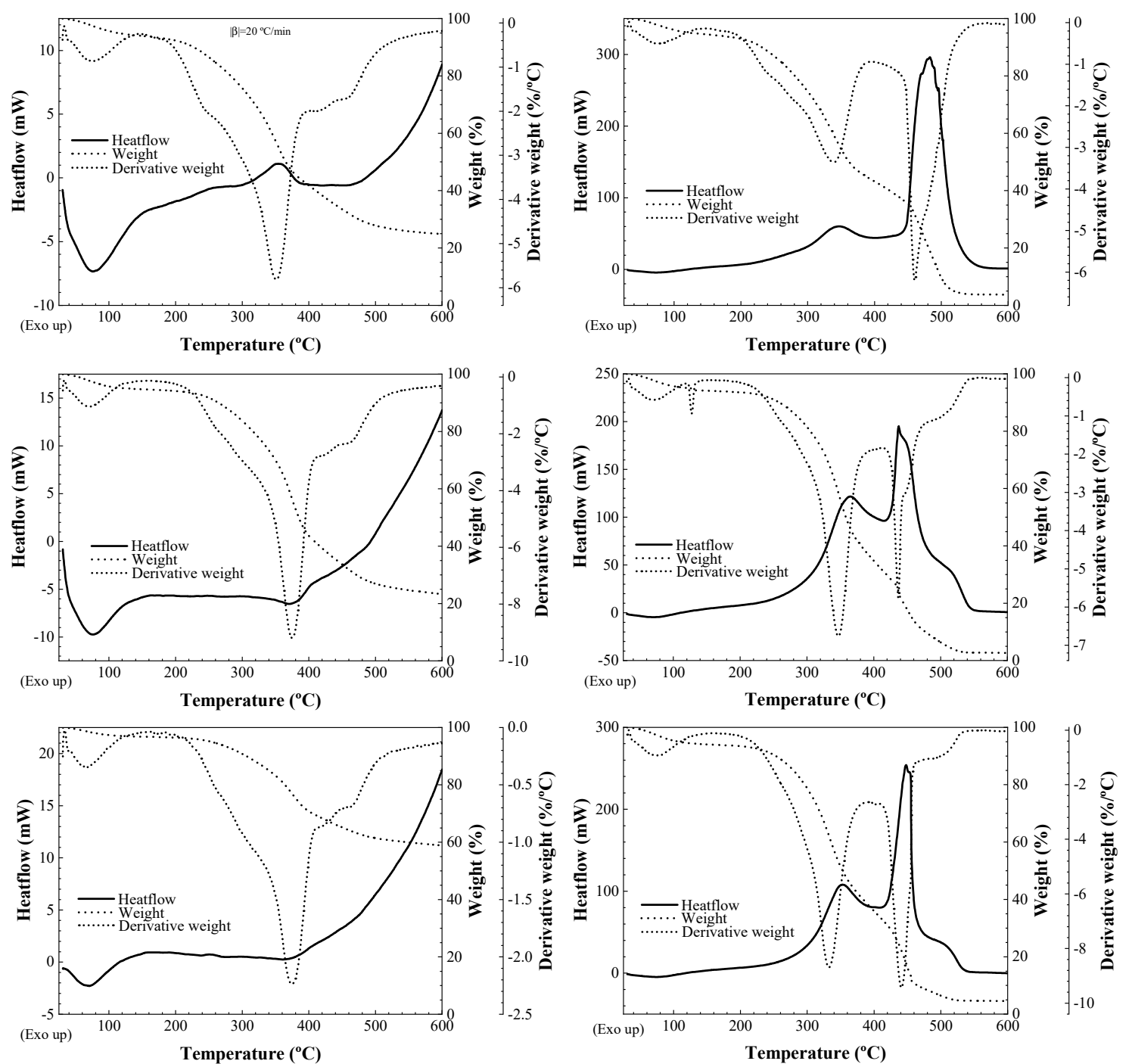

Figure 3. Differential scanning calorimetry (solid line, y-axis on the left), thermogravimetry (dashed line, first y-axis on the right) and derivative thermogravimetry (dotted line, second y-axis on the right) curves of E. horridum fractions: (top) green stems or leaves; (center) brown stems; (bottom) twigs. Graphs on the left correspond to thermograms obtained in inert $\left(\mathrm{N}_{2}\right)$ conditions, while those on the right were obtained in oxidative conditions $\left(\mathrm{O}_{2}\right)$. All thermograms were obtained at a heating rate of $20{ }^{\circ} \mathrm{C} \cdot \mathrm{min}^{-1}$.

\subsection{Vibrational Spectroscopy Characterization}

Fourier-transform infrared (FTIR) spectra (Figure 4), apart from evidencing the presence of lignin, cellulose and hemicellulose, indicated the presence of the flavone nucleus [20], since they displayed absorption bands at $3289 \mathrm{~cm}^{-1}(\mathrm{OH}), 1640 \mathrm{~cm}^{-1}$ (conjugated double bond) and $1613 \mathrm{~cm}^{-1}$ (conjugated and chelated $\gamma$-pyrone carbonyl), as shown in Table 5. 


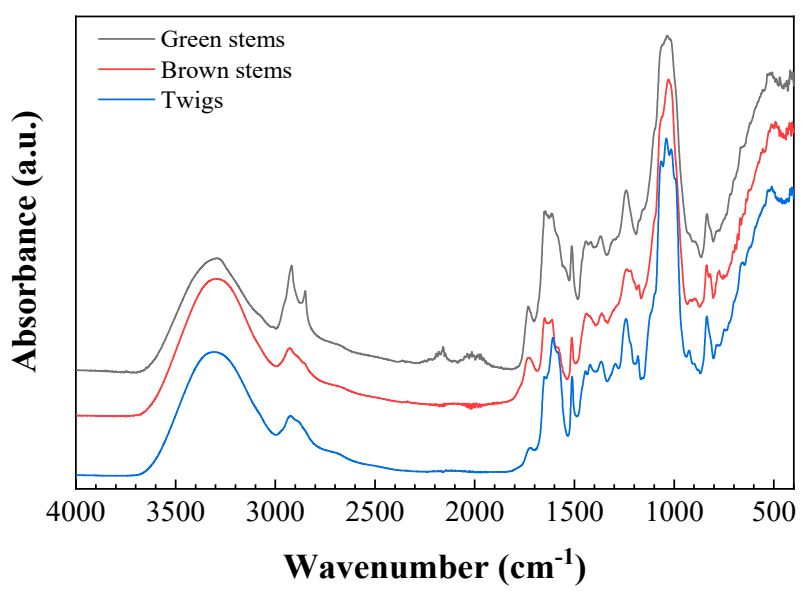

Figure 4. Infrared spectra of the different fractions of E. horridum.

Table 5. Main absorption bands in the infrared spectra shown in Figure 4, together with their assignments [21-24].

\begin{tabular}{|c|c|c|c|}
\hline Wavenumber $\left(\mathrm{cm}^{-1}\right)$ & Vegetal Component & Bonds & Assignments \\
\hline $3288-3308$ & & $\mathrm{OH}$ & \\
\hline $2917-2927$ & $\begin{array}{c}\text { Cellulose, } \\
\text { hemicellulose, lignin }\end{array}$ & $\mathrm{CH}$ stretch & \\
\hline $2849-2850$ & $\begin{array}{c}\text { Cellulose, } \\
\text { hemicellulose, lignin }\end{array}$ & $\mathrm{CH}$ stretch & Symmetric $\mathrm{CH}_{2}$ valence vibration \\
\hline $1727-1733$ & Hemicellulose, lignin & $\mathrm{C}=\mathrm{O}$ & $\begin{array}{l}\text { Ester linkage of the carboxylic group of } \\
\text { p-coumaric and ferulic acids }\end{array}$ \\
\hline $1648-1652$ & Flavone nucleus & & Conjugated double bond \\
\hline $1621-1625$ & Cellulose, lignin & $\mathrm{O}-\mathrm{H}, \mathrm{C}-\mathrm{O}$ & $\mathrm{O}-\mathrm{H}$ and conjugated $\mathrm{C}-\mathrm{O}$ \\
\hline $1612-1614$ & Flavone nucleus & $\mathrm{C}=\mathrm{O}$ & Conjugated and chelated $\gamma$-pyrone carbonyl \\
\hline $1541-1558$ & & & Aromatic ring \\
\hline $1514-1516$ & Lignin & $\mathrm{C}=\mathrm{C}$ & Stretching vibrations of aromatic structure \\
\hline $1437-1443$ & Saccharide backbone & $\mathrm{C}-\mathrm{H}$ & $\begin{array}{l}\text { Alkane deformation relating to } \mathrm{CH} \text { and } \mathrm{CH}_{2} \\
\text { consistent with the saccharide backbone }\end{array}$ \\
\hline 1417 & & $\mathrm{C}=\mathrm{C}$ & $\mathrm{C}=\mathrm{C}$ ring stretching \\
\hline $1363-1370$ & Cellulose & $\mathrm{C}-\mathrm{H}$ & $\begin{array}{l}\text { In-plane bending vibration of the } \mathrm{C}-\mathrm{H} \text { and } \\
\mathrm{C}-\mathrm{O} \text { groups of the hexose ring }\end{array}$ \\
\hline 1316 & $\begin{array}{c}\text { Cellulose, } \\
\text { hemicellulose, lignin }\end{array}$ & $\mathrm{C}-\mathrm{O}, \mathrm{CH}_{2}$ & $\begin{array}{l}\text { Condensation of the guaiacyl unit and syringyl } \\
\text { unit; syringyl unit and } \mathrm{CH}_{2} \text { bending stretching; } \\
\qquad \mathrm{CH}_{2} \text { rocking vibration }\end{array}$ \\
\hline $1237-1240$ & Lignin & $\mathrm{C}-\mathrm{H}$ & $\begin{array}{c}\mathrm{C}-\mathrm{C} \text { plus } \mathrm{C}-\mathrm{O} \text { plus } \mathrm{C}=\mathrm{O} \text { stretching }(\mathrm{OH} \text { plane } \\
\text { deformation, also } \mathrm{COOH})\end{array}$ \\
\hline 1178 & & $\mathrm{C}-\mathrm{H}$ & \\
\hline 1151 & Cellulose & $\mathrm{C}-\mathrm{H}$ & $\begin{array}{c}\mathrm{C}-\mathrm{O}-\mathrm{C} \text { asymmetric valence vibration, } \mathrm{C}=\mathrm{O} \\
\text { stretching in aliphatic group }\end{array}$ \\
\hline $1027-1035$ & $\begin{array}{c}\text { Cellulose, } \\
\text { hemicellulose, lignin }\end{array}$ & $\begin{array}{c}\mathrm{C}-\mathrm{O}, \mathrm{C}=\mathrm{C} \text { and } \\
\mathrm{C}-\mathrm{C}-\mathrm{O}\end{array}$ & $\begin{array}{c}\text { Aromatic } \mathrm{C}-\mathrm{H} \text { in plane deformation; plus } \mathrm{C}-\mathrm{O} \\
\text { deformation in alcohols; plus } \mathrm{C}=\mathrm{O} \\
\text { stretch (unconjugated) }\end{array}$ \\
\hline
\end{tabular}




\subsection{High Added-Value Products Characterization and Quantification}

\subsubsection{Identification}

The electrospray ionization quadrupole time-of-flight mass spectrometry (ESI Q-TOF MS) spectrum in positive ionization mode featured peaks at $m / z 447,365,285,247,187,145$ and 124 (Figure 5), which led to the identification of flavonoids and other compounds present in E. horridum.

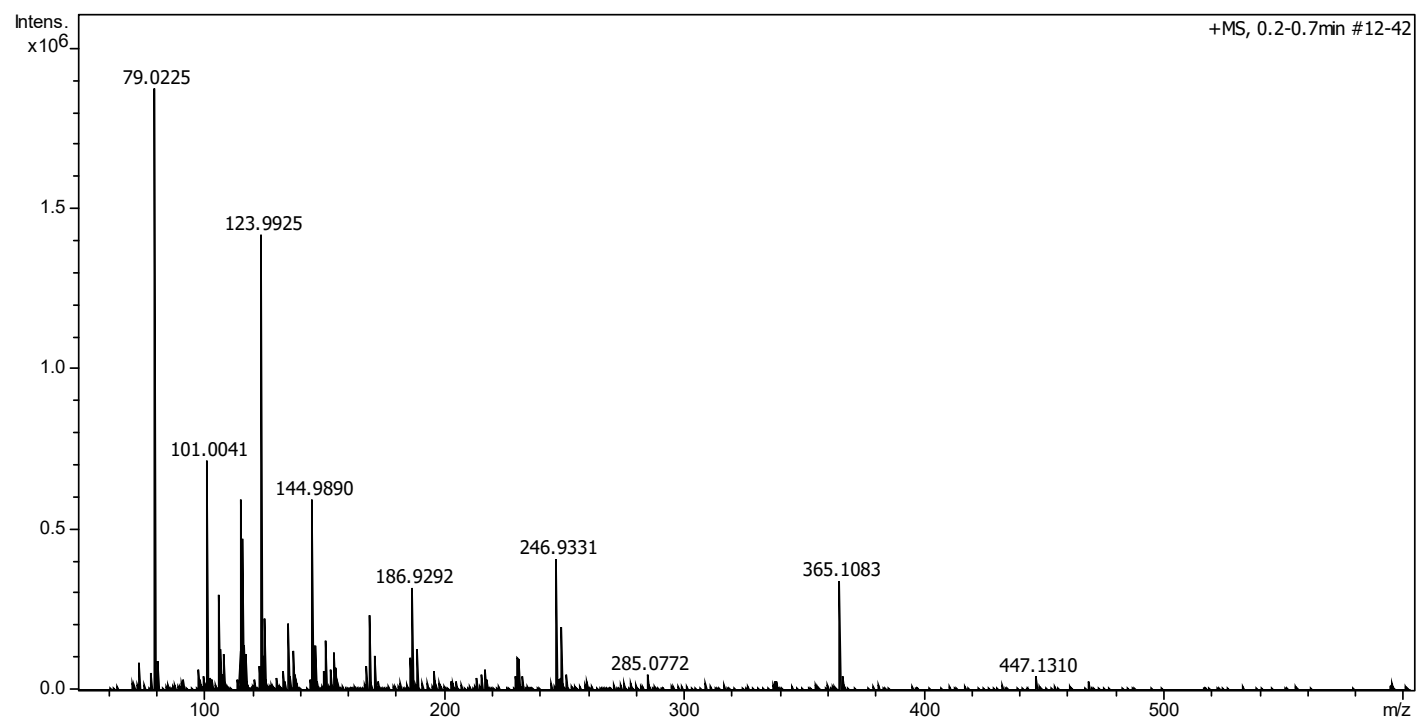

Figure 5. Electrospray ionization quadrupole time-of-flight mass spectrometry (ESI Q-TOF MS) spectrum of E. horridum in positive mode.

While in hydrolyzed leaves of Erinacea anthyllis Lynk, the identified flavonoids were daidzein, genistein and isoprunetin [10], in E. horridum, the main flavonoid would be genkwanin, $[\mathrm{M}+\mathrm{H}]^{+} m / z=285$, a monomethoxyflavone that derives from apigenin (Figure 6), which is structurally close to isoprunetin (5-O-methylgenistein). Genkwanin shows inhibitory effects on breast cancer resistance protein (BCRP) [25] and inhibition of African swine fever virus infection [26]. Provided that the anhydro-glucopyranoside moiety, Glc $p$, is exactly $162 \mathrm{Da}$, the precursor peak at $m / z=447$ should be assigned to its $4^{\prime}-O-\beta$-D-glucopyranoside derivative.<smiles>COc1cc(O)c2c(=O)cc(-c3ccc(O)cc3)oc2c1</smiles>

Genkwanin<smiles>COc1cc2cc3c(c(-c4ccc5c(c4)OCO5)c2cc1OC)C(=O)OC3</smiles>

Justicidin B

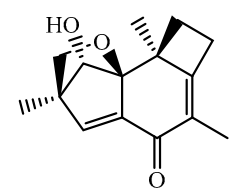

Radulone A

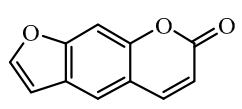

Psoralen

Figure 6. From left to right: genkwanin, justicidin B, radulone A and psoralen.

Other interesting natural chemical components present in E. horridum would be justicidin B (an arylnaphthalene lignin, $[\mathrm{M}+\mathrm{H}]^{+} \mathrm{m} / \mathrm{z}=365$ ), with applications in cancer chemotherapy [27] and as an antiviral [28]; the illudane type-sesquiterpene radulone $\mathrm{A},[\mathrm{M}+\mathrm{H}]^{+} \mathrm{m} / \mathrm{z}=247$; and the linear furanocoumarin psoralen, $[\mathrm{M}+\mathrm{H}]^{+} \mathrm{m} / \mathrm{z}=186$, with activity against breast cancer [29] (Figure 6).

The peak at $\mathrm{m} / \mathrm{z}=124$ can be associated to the $\mathrm{m} / \mathrm{z}=285$ fragment by neutral loss of a monosaccharide molecule (-161); that at $\mathrm{m} / \mathrm{z}=101$ can to correspond to the $\mathrm{m} / \mathrm{z}=145$ fragment ion via loss of a $\mathrm{CO}_{2}$ group from the carboxylic acid; and the peak $m / z=79$ to $\left[\mathrm{C}_{6} \mathrm{H}_{7}\right]^{+}$. Finally, the peak at $m / z=145$ can be associated either to a sugar fragment $\left[\mathrm{C}_{7} \mathrm{H}_{13} \mathrm{O}_{3}\right]^{+}$or to protonated $\alpha$-naphtol, $\left[\mathrm{C}_{10} \mathrm{H}_{9} \mathrm{O}\right]^{+}$. 


\subsubsection{Genkwanin Quantification}

For the economic justification of the pharmacological use of the studied shrub plant, if the isolation of the aforementioned compounds is considered, information on their content is very important from the point of view of the efficiency of the process. Hence, genkwanin content was determined for the leaves/green stems fraction by HPLC analysis. The yield attained for this bioactive compound using methanol extraction under heating and stirring was $0.21 \pm 0.04 \mathrm{mg} / \mathrm{g}(n=3)$. This content is $25 \%$ lower than the one reported by Qi et al. [30] for Equisetum palustre L. $(0.28 \mathrm{mg} / \mathrm{g})$ and an order of magnitude lower than the values found by Lin et al. [31] in Daphne genkwa Sieb et Zucc. flowers (3.7 mg/g).

\subsection{Opportunities for Valorization}

The shrub species under study, E. horridum, yielded LHV and HHV values compliant with the requirements of solid biofuel standards. Nonetheless, its biomass ash content was slightly above the maximum established in the European normative for wood pellets ( $2 \%)$, which would preclude their utilization as fuelwood in rural district heating. Since the ash content depends on the dryness of the plants to be used as fuel, only old specimens (entirely brown stems) should be harvested in order to meet the regulatory requirements.

An alternative application, with a higher added-value, would be the one derived from the pharmacological use of some flavonoids (genkwanin) and lignans (justicidin B) present in its composition. These components, upon administration, show dominant anti-tumor and antiviral activities. At present, genkwanin market price exceeds $200 € / 10 \mathrm{mg}$, which could make the felling and harvesting of these shrubs a profitable activity if higher extraction yields can be attained. It should be taken into consideration that the amount reported above $(0.21 \mathrm{mg} / \mathrm{g})$ may be regarded as a lower bound estimate, given that genkwanin-5-O- $\beta$-D-glucopyranoside was not quantified and that the extraction conditions had not been optimized.

The use of modern extractive approaches, such as dynamic maceration process [32] or ionic liquid analogs (deep eutectic solvents) as extractive solvents [33], negative pressure cavitation-assisted extraction with macroporous resin enrichment [30], microwave-assisted extraction, high-speed countercurrent chromatography [34], etc. should be explored to find an effective preparative method for the isolation and purification of flavonoids from E. horridum.

\section{Material and Methods}

\subsection{Sampling}

The E. horridum samples under study were collected in Monrepós pass, Huesca, Spain $\left(42^{\circ} 18.9890^{\prime} \mathrm{N}\right.$, $0^{\circ} 16.6929^{\prime}$ W, 1191.2 m.a.s.1.) in May 2019. They corresponded to healthy individuals and their characteristics were akin to those of the rest of the population. Just the aerial part was used in the study, given that excavation of the root system would not be viable for the commercial exploitation of this shrub.

\subsection{Fuel Characterization and Biomass Combustion Properties}

The selected samples were processed at the Escuela Politécnica Superior facilities (Universidad de Zaragoza, Huesca, Spain), separating the various fractions and weighing them (fresh weight). Subsamples from each fraction, dried in an oven at $102 \pm 2{ }^{\circ} \mathrm{C}$ until constant weight was attained (at which the water content was assumed to be zero), were used for the determination of the dry matter content.

Prior to the physicochemical characterization, each dried biomass fraction was ground into powder in a ball mill, homogenized, and sieved (1 mm mesh).

Elemental (CHNS) analyses of the dry ground samples were performed using a TruSpec Micro (LECO, St. Joseph, MI, USA) apparatus. 
Thermal analysis was conducted with a TG-DSC2 instrument (Mettler Toledo; Columbus, OH, USA). The samples were heated at a rate of $20^{\circ} \mathrm{C} \cdot \mathrm{min}^{-1}$ from 30 to $600{ }^{\circ} \mathrm{C}$, under both $\mathrm{N}_{2}$ and air flow $\left(20 \mathrm{~cm}^{3} \cdot \mathrm{min}^{-1}\right)$. The ash content was estimated from the residue obtained after heating at $600{ }^{\circ} \mathrm{C}$, in agreement with the usual pyrolysis temperature conditions in oxygen bomb calorimeters [35].

Calorific Values Calculation

The calculation of calorific values from elemental analysis data was carried out according Equation (1) [36]:

$$
\mathrm{HHV}=(0.341 \times \% \mathrm{C})+(1.322 \times \% \mathrm{H})-0.12(\% \mathrm{O}+\% \mathrm{~N}),
$$

where $\mathrm{HHV}$ is the heating value for the dry material, expressed in $\mathrm{MJ} / \mathrm{kg}$, and $\% \mathrm{C}, \% \mathrm{H}, \% \mathrm{O}$ and $\% \mathrm{~N}$ are the mass fractions, expressed in $\mathrm{w} t \%$ of dry material. This formula gives acceptable results for biomass, according to the UK's Combined Heat and Power Quality Assurance program [37].

\subsection{Vibrational Characterization}

The infrared vibrational spectra were acquired using a Nicolet iS50 FTIR spectrometer (Thermo Scientific; Waltham, MA, USA), equipped with an in-built diamond attenuated total reflection (ATR) system. The spectra were collected with a $1 \mathrm{~cm}^{-1}$ spectral resolution over the $400-4000 \mathrm{~cm}^{-1}$ range, taking the interferograms that resulted from co-adding 64 scans.

\subsection{Extraction Process and High-Added Value Products Characterization and Quantification}

\subsubsection{Extraction Process}

The extraction process was analogous to that used by Lin et al. [31]. A sample of E. horridum leaves/green stems fraction $(1.0 \mathrm{~g})$ was extracted three times with $70 \%$ methanol at $80{ }^{\circ} \mathrm{C}$ for one hour. The extracts were combined and methanol was added to $150 \mathrm{~mL}$. This solution was filtered through a $0.45 \mu \mathrm{m}$ filter before use.

\subsubsection{Electrospray Ionization Quadrupole Time-of-Flight Mass Spectrometry (ESI-Q-TOF} MS) Characterization

For the identification of the various compounds present in the extract, the high-resolution mass spectrum was measured on a Maxis Impact spectrometer (Bruker Daltonik GmbH, Bremen, Germany) using direct infusion ESI Q-TOF MS. The spectrometer was operated in linear positive mode in the $\mathrm{m} / \mathrm{z}$ range of 50-600 Da, under the following conditions: $3.5 \mathrm{kV}$ potential between spray needle and orifice, 0.4 bar nebulizer pressure, $3.0 \mathrm{~L} \cdot \mathrm{min}^{-1}$ drying gas flow rate at $200{ }^{\circ} \mathrm{C}$, and $3.0 \mu \mathrm{L} \cdot \mathrm{min}^{-1}$ sample flow rate [38]. The analysis was outsourced at the Laboratorio de Técnicas Instrumentales facilities of Universidad de Valladolid.

\subsubsection{Genkwanin Quantification}

In order to estimate the content of the most important high-added value product (genkwanin) detected in E. horridum extract, high-performance liquid chromatography (HPLC) analysis was conducted using an Agilent 1200 HPLC system (Agilent Technologies; San Jose, CA, USA). The chromatographic separation was carried out on a Curosil ${ }^{\mathrm{TM}}$-PFP (pentafluorophenyl) column $\left(250 \times 4.6 \mathrm{~mm}\right.$ i.d., $5 \mu \mathrm{m}$, Phenomenex, Torrance, CA, USA), whose temperature was kept at $30^{\circ} \mathrm{C}$. The gradient elution program was the one described by Qi et al. [30], using $0.1 \%$ formic acid aqueous solution and methanol. An injection volume of $5 \mu \mathrm{L}$ and a flow rate of $1.0 \mathrm{~mL} \cdot \mathrm{min}^{-1}$ were used. The detection wavelength was $330 \mathrm{~nm}$. Genkwanin ( $\geq 98 \%$ ) supplied by Sigma-Aldrich was taken as a reference standard. 


\section{Conclusions}

Based on the thermal characterization results, Echinospartum horridum biomass does not comply with ISO 17225-2:2014 requirements for its valorization as a fuel. Even though its HHV and LHV calorific values (25.6 and $18.3 \mathrm{~kJ} \cdot \mathrm{g}^{-1}$, respectively) meet the requirements for its use in pellets, the ash content (2.7-4.5\%, depending on the specific fraction) exceeds the established limit $(<2 \%)$, so it would not comply with the normative for its acceptable use as a fuel. Nonetheless, the presence of genkwanin, justicidin B, radulone A and psoralen high added-value by-products in its extracts may offer a promising alternative for the valorization of this neglected and underutilized natural resource of Pyrenean shrublands in pharmacology.

Author Contributions: Conceptualization, J.M.-G. and J.A.C.-O.; Formal analysis, P.M.-R., J.M.-G., D.G.-G. and J.A.C.-O.; Investigation, P.M.-R. and J.M.-G.; Methodology, J.M.-G., D.G.-G. and J.A.C.-O.; Resources, J.M.-G.; Validation, J.M.-G., D.G.-G. and J.A.C.-O.; Visualization, P.M.-R.; Writing—original draft, P.M.-R., J.M.-G., D.G.-G. and J.A.C.-O.; Writing-review and editing, P.M.-R., J.M.-G., D.G.-G. and J.A.C.-O. All authors have read and agreed to the published version of the manuscript.

Funding: This research received no external funding.

Acknowledgments: J. Nocito is gratefully acknowledged for his valuable comments.

Conflicts of Interest: The authors declare no conflict of interest.

\section{References}

1. Gómez, D.; Mateo, G.; Mercadal, N.; Montserrat, P.; Sesé, J.A. Atlas de la Flora de Aragón. Available online: http://floragon.ipe.csic.es/index.php (accessed on 11 July 2020).

2. Palacio, S.; Millard, P.; Montserrat-Martí, G. Aboveground biomass allocation patterns within Mediterranean sub-shrubs: A quantitative analysis of seasonal dimorphism. Flora-Morphol. Distrib. Funct. Ecol. Plants 2006, 201, 612-622. [CrossRef]

3. Palacio, S.; Montserrat-Martí, G. Above and belowground phenology of four Mediterranean sub-shrubs. Preliminary results on root-shoot competition. J. Arid Environ. 2007, 68, 522-533. [CrossRef]

4. Komac, B.; Kefi, S.; Nuche, P.; Escós, J.; Alados, C.L. Modeling shrub encroachment in subalpine grasslands under different environmental and management scenarios. J. Environ. Manag. 2013, 121, 160-169. [CrossRef] [PubMed]

5. Badía, D.; Armas Herrera, C.M.; Mora Hernández, J.L.; Gómez, D.; Montserrat Martí, G.; Palacios, S. ¿Podemos controlar la expansión del erizón mediante quemas? Lucas Mallada Rev. Cienc. 2017, 19, $69-94$.

6. Badía, D.; López-García, S.; Martí, C.; Ortíz-Perpiñá, O.; Girona-García, A.; Casanova-Gascón, J. Burn effects on soil properties associated to heat transfer under contrasting moisture content. Sci. Total Environ. 2017, 601-602, 1119-1128. [CrossRef] [PubMed]

7. Palacio, S.; Milla, R.; Albuixech, J.; Pérez-Rontomé, C.; Camarero, J.J.; Maestro, M.; Montserrat-Martí, G. Seasonal variability of dry matter content and its relationship with shoot growth and nonstructural carbohydrates. New Phytol. 2008, 180, 133-142. [CrossRef]

8. Marinas, A.; García-González, R.; Fondevila, M. The nutritive value of five pasture species occurring in the summer grazing ranges of the Pyrenees. Anim. Sci. 2016, 76, 461-469. [CrossRef]

9. Mora, J.L.; Armas, C.; Badía, D.; Montserrat, G.; Palacio, S.; Gómez, D. Evaluación de la calidad bromatológica del erizón tras el uso de fuego prescrito para la mejora de pastos en el Pirineo Central. In Proceedings of $57^{\circ}$ Reunión Científica de la Sociedad Española de Pastos; Roig, S., Barrantes, O., Eds.; Sociedad Española de Pastos: Teruel, Spain, 2018; pp. 142-150.

10. Harborne, J. Chemosystematics of the Leguminosae. Flavonoid and isoflavonoid patterns in the tribe Genisteae. Phytochemistry 1969, 8, 1449-1456. [CrossRef]

11. Grayer-Barkmeijer, R.J.; Ingham, J.L.; Dewick, P.M. 5-O-methylbiochanin a, a new isoflavone from Echinospartum horridum. Phytochemistry 1978, 17, 829-830. [CrossRef]

12. Carrión-Prieto, P.; Hernández-Navarro, S.; Martín-Ramos, P.; Sánchez-Sastre, L.F.; Garrido-Laurnaga, F.; Marcos-Robles, J.L.; Martín-Gil, J. Mediterranean shrublands as carbon sinks for climate change mitigation: New root-to-shoot ratios. Carbon Manag. 2017, 8, 67-77. [CrossRef] 
13. García Rosa, M. Estudio de la Biomasa de Cistus ladanifer L. y Retama sphaerocarpa L. como Sumidero de $\mathrm{CO}_{2}$ : Existencias y Potencialidad. Ph.D. Thesis, Universidad de Extremadura, Badajoz, Spain, 2013.

14. Carrión-Prieto, P.; Martín-Ramos, P.; Hernández-Navarro, S.; Sánchez-Sastre, L.F.; Marcos-Robles, J.L.; Martín-Gil, J. Valorization of Cistus ladanifer and Erica arborea shrubs for fuel: Wood and bark thermal characterization. Maderas Cienc. Tecnol. 2017, 19, 443-454. [CrossRef]

15. European Pellet Council. Handbook for the Certification of Wood Pellets for Heating Purposes, Based on EN 14961-2; European Pellet Council: Brussels, Belgium, 2011;33p.

16. International Organization for Standardization. Solid Biofuels, Fuel Specifications and Classes. Part 2: Graded Wood Pellets; International Organization for Standardization: Geneva, Switzerland, 2014; Volume 17225-2:2014, 9p.

17. Energy Research Centre of the Netherlands. ECN Phyllis2 Database for Biomass and Waste. Available online: https://www.ecn.nl/phyllis2 (accessed on 6 August 2017).

18. Reed, T.B.; Das, A. Handbook of Biomass Downdraft Gasifier Engine Systems; U.S. Department of Energy, Solar Energy Research Institute: Golden, CO, USA, 1988; 149p.

19. ENplus. ENplus Handbook Version 3.0; European Biomass Association AEBIOM: Brussels, Belgium, 2015; 103p.

20. Jose, C.I.; Phadke, P.S.; Rao, A.V.R. Infrared spectra of flavones and isoflavones: Effect of iodine and boron trifluoride on carbonyl frequencies. Spectrochim. Acta Part A Mol. Spectrosc. 1974, 30, 1199-1206. [CrossRef]

21. Emmanuel, V.; Odile, B.; Céline, R. FTIR spectroscopy of woods: A new approach to study the weathering of the carving face of a sculpture. Spectrochim. Acta Part A Mol. Biomol. Spectrosc. 2015, 136, 1255-1259. [CrossRef] [PubMed]

22. Faust, B. Modern Chemical Techniques: An Essential Reference for Students and Teachers; Royal Society of Chemistry: London, UK, 1997.

23. Schwanninger, M.; Rodrigues, J.C.; Pereira, H.; Hinterstoisser, B. Effects of short-time vibratory ball milling on the shape of FT-IR spectra of wood and cellulose. Vib. Spectrosc. 2004, 36, 23-40. [CrossRef]

24. Traoré, M.; Kaal, J.; Martínez Cortizas, A. Application of FTIR spectroscopy to the characterization of archeological wood. Spectrochim. Acta Part A Mol. Biomol. Spectrosc. 2016, 153, 63-70. [CrossRef]

25. Fan, X.; Bai, J.; Zhao, S.; Hu, M.; Sun, Y.; Wang, B.; Ji, M.; Jin, J.; Wang, X.; Hu, J.; et al. Evaluation of inhibitory effects of flavonoids on breast cancer resistance protein (BCRP): From library screening to biological evaluation to structure-activity relationship. Toxicol. In Vitro 2019, 61, 104642. [CrossRef]

26. Hakobyan, A.; Arabyan, E.; Kotsinyan, A.; Karalyan, Z.; Sahakyan, H.; Arakelov, V.; Nazaryan, K.; Ferreira, F.; Zakaryan, H. Inhibition of African swine fever virus infection by genkwanin. Antivir. Res. 2019, 167, 78-82. [CrossRef]

27. Hemmati, S.; Seradj, H. Justicidin B: A promising bioactive lignan. Molecules 2016, 21, 820. [CrossRef]

28. MacRae, W.; Hudson, J.; Towers, G. The antiviral action of lignans. Planta Med. 2007, 55, 531-535. [CrossRef]

29. Du, M.; Ouyang, Y.; Meng, F.; Zhang, X.; Ma, Q.; Zhuang, Y.; Liu, H.; Pang, M.; Cai, T.; Cai, Y. Polymer-lipid hybrid nanoparticles: A novel drug delivery system for enhancing the activity of Psoralen against breast cancer. Int. J. Pharm. 2019, 561, 274-282. [CrossRef]

30. Qi, X.-L.; Peng, X.; Huang, Y.-Y.; Li, L.; Wei, Z.-F.; Zu, Y.-G.; Fu, Y.-J. Green and efficient extraction of bioactive flavonoids from Equisetum palustre L. by deep eutectic solvents-based negative pressure cavitation method combined with macroporous resin enrichment. Ind. Crop. Prod. 2015, 70, 142-148. [CrossRef]

31. Lin, J.H.; Lin, Y.T.; Chiou, Y.N.; Wen, K.C.; Liao, C.H. Determination of flavonoids in Daphnis Genkwae Flos by high performance liquid chromatography. J. Food Drug Anal. 2020, 9, 1-5. [CrossRef]

32. Pereira, S.V.; Reis, R.A.S.P.; Garbuio, D.C.; Freitas, L.A.P.d. Dynamic maceration of Matricaria chamomilla inflorescences: Optimal conditions for flavonoids and antioxidant activity. Rev. Bras. Farmacogn. 2018, 28, 111-117. [CrossRef]

33. Zainal-Abidin, M.H.; Hayyan, M.; Hayyan, A.; Jayakumar, N.S. New horizons in the extraction of bioactive compounds using deep eutectic solvents: A review. Anal. Chim. Acta 2017, 979, 1-23. [CrossRef] [PubMed]

34. Xie, H.; Liang, Y.; Ito, Y.; Wang, X.; Chen, R.; He, J.; Li, H.; Zhang, T. Preparative isolation and purification of four flavonoids from Daphne genkwa Sieb. et Zucc. by high-speed countercurrent chromatography. J. Liq. Chromatogr. Relat. Technol. 2011, 34, 2360-2372. [CrossRef]

35. Wang, F.; Hu, L.J.; Zheng, Y.W.; Huang, Y.B.; Yang, X.Q.; Liu, C.; Kang, J.; Zheng, Z.F. Regulation for Optimal Liquid Products during Biomass Pyrolysis: A Review. IOP Conf. Ser. Earth Environ. Sci. 2016, 40, 012047. [CrossRef] 
36. Talwalkar, A.T.; U.S. Department of Energy, Institute of Gas Technology. IGT/DOE Coal-Conversion Systems Technical Data Book; Institute of Gas Technology: Chicago, IL, USA, 1981; 23p.

37. CHPQA. Guidance Note 29: Alternative Fuels_Energy Inputs; UK Combined Heat \& Power Quality Assurance Programme: London, UK, 2008; 6p.

38. Kozłowska, J.; Grela, E.; Baczyńska, D.; Grabowiecka, A.; Anioł, M. Novel O-alkyl derivatives of naringenin and their oximes with antimicrobial and anticancer activity. Molecules 2019, 24, 679. [CrossRef] [PubMed] 